\title{
International Cooperation to Address the Radioactive Legacy in States of the Former Soviet Union
}

D.K. Smith, R.B. Knapp, N.D. Rosenberg, A.F.B. Tompson

This article was submitted to Erice International Seminars on Nuclear War, Planetary Emergencies and Associated Events Erice, Italy

August 18-26, 2003

U.S. Department of Energy

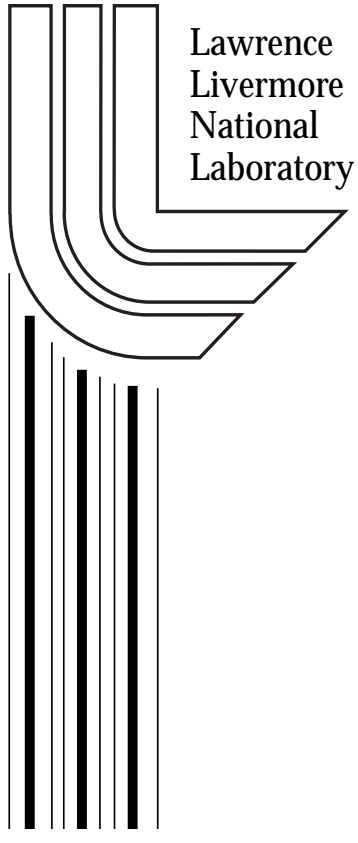

\section{July 27, 2003}




\section{DISCLAIMER}

This document was prepared as an account of work sponsored by an agency of the United States Government. Neither the United States Government nor the University of California nor any of their employees, makes any warranty, express or implied, or assumes any legal liability or responsibility for the accuracy, completeness, or usefulness of any information, apparatus, product, or process disclosed, or represents that its use would not infringe privately owned rights. Reference herein to any specific commercial product, process, or service by trade name, trademark, manufacturer, or otherwise, does not necessarily constitute or imply its endorsement, recommendation, or favoring by the United States Government or the University of California. The views and opinions of authors expressed herein do not necessarily state or reflect those of the United States Government or the University of California, and shall not be used for advertising or product endorsement purposes.

This is a preprint of a paper intended for publication in a journal or proceedings. Since changes may be made before publication, this preprint is made available with the understanding that it will not be cited or reproduced without the permission of the author.

This report has been reproduced directly from the best available copy.

Available electronically at http://www.doc.gov/bridge

Available for a processing fee to U.S. Department of Energy

And its contractors in paper from

U.S. Department of Energy

Office of Scientific and Technical Information

P.O. Box 62

Oak Ridge, TN 37831-0062

Telephone: (865) 576-8401

Facsimile: (865) 576-5728

E-mail: reports@adonis.osti.gov

Available for the sale to the public from

U.S. Department of Commerce

National Technical Information Service

5285 Port Royal Road

Springfield, VA 22161

Telephone: (800) 553-6847

Facsimile: (703) 605-6900

E-mail: orders@ntis.fedworld.gov

Online ordering: http://www.ntis.gov/ordering.htm

OR

Lawrence Livermore National Laboratory

Technical Information Department's Digital Library

http://www.llnl.gov/tid/Library.html 


\title{
INTERNATIONAL COOPERATION TO ADDRESS THE RADIOACTIVE LEGACY IN STATES OF THE FORMER SOVIET UNION
}

\author{
David K. Smith, Richard B. Knapp, Nina D. Rosenberg, and Andrew F.B. Tompson \\ Lawrence Livermore National Laboratory \\ Livermore, CA 94550 USA
}

The end of the Cold War allows a comprehensive assessment of the nature and extent of the residual contamination derivative from the atomic defense and nuclear power enterprise in the former Soviet Union. The size of the problem is considerable; some 6.3 $\mathrm{x} 10^{7} \mathrm{TBq}\left(6.4 \times 10^{8} \mathrm{~m}^{3}\right)$ of radioactive waste from the Soviet Union weapons and power complex was produced throughout all stages of the nuclear fuel cycle. The resulting contamination occurs at sites throughout the former Soviet Union where nuclear fuels were mined, milled, enriched, fabricated, and used in defense and power reactors. In addition, liquid radioactive wastes from nuclear reprocessing have been discharged to lakes, rivers, reservoirs and other surface impoundments; military and civilian naval reactor effluents were released to sea as well as stabilized on land. Finally, nuclear testing residuals from atmospheric and underground nuclear tests at the Semipalatinsk and Novaya Zemlya test sites and peaceful nuclear tests conducted throughout the area of the former Soviet Union pose risks to human health and the environment (Figure 1).

Through a program of international scientific exchange, cooperative approaches to address these threats provide former Soviet scientists with expertise and technologies developed in the United States, Europe, and elsewhere to design comprehensive and long term remedial solutions.

The role of the international community to address these challenges is essential because the emerging states of the former Soviet Union share common nuclear residuals that cross newly established national borders. In addition, the widespread post-Soviet radioactive contamination hampers economic recovery and - in some cases - poses proliferation concerns. Also important is the widespread perception throughout these countries that the Soviet nuclear legacy poses a grave threat to the human population. A new paradigm of "national security" encompasses more than the historical activities of nuclear weapon production, testing, and deterrence and now includes the environment, human and economic health, and the proliferation of weapons-of-mass destruction ${ }^{1}$. For these reasons the fall of the Soviet Union provides a new imperative and opportunity for systematic, comprehensive and interdisciplinary international efforts to begin to solve these important environmental problems.

The environmental degradation from nuclear contamination affecting states of the former Soviet Union is a large topic, and a full description is outside the scope of this paper. A comprehensive overview of environmental concerns and radioactive waste production, inventories, and impacted sites is provided by others ${ }^{2,3,4}$. Portions of the summaries provided here are drawn from these works. 
Table I summarizes the current extent of radioactive contamination and state of waste management practice in the former Soviet Union ${ }^{2}$.

Table I

Summary of Radioactive Contamination in the former Soviet Union

\begin{tabular}{|c|c|}
\hline Source in Nuclear Fuel Cycle & Radioactive Contamination and Waste Management \\
\hline Uranium mining and milling & $\begin{array}{l}\text { Waste storage in tailings piles. Liquid waste stored in } \\
\text { impoundments or discharged to the environment. Total } \\
\text { activity is } 3.7 \times 10^{3} \mathrm{TBq} \text {. }\end{array}$ \\
\hline $\begin{array}{l}\text { Uranium conversion, } \\
\text { enrichment and fuel } \\
\text { fabrication }\end{array}$ & $\begin{array}{l}\text { Liquid and solid waste stored at specific site facilities. } \\
\text { Total activity is } 1.48 \times 10^{2} \mathrm{TBq} \text {. }\end{array}$ \\
\hline $\begin{array}{l}\text { Commercial nuclear power } \\
\text { plants }\end{array}$ & $\begin{array}{l}\text { Liquid wastes stored on-site in tanks; solidification of } \\
\text { liquid waste. Solid wastes stored on-site. Total } \\
\text { activity is } 1.5 \times 10^{3} \mathrm{TBq} \text { (liquid concentrates). }\end{array}$ \\
\hline Commercial spent fuel & Stored at reactor sites. Total activity is $1.5 \times 10^{8} \mathrm{TBq}$. \\
\hline Defense reactors & Cooling water discharge to lakes at Mayak Site. \\
\hline Reprocessing wastes & $\begin{array}{l}\text { Liquid waste discharged to ponds, lakes and rivers. } \\
\text { Widespread releases at Mayak to Techna River and } \\
\text { Lake Karachai. Other releases at Tomsk-7 and } \\
\text { Krasnoyarsk-26. Total activity is } 2.1 \times 10^{7} \mathrm{TBq} \text { (liquid } \\
\text { wastes). }\end{array}$ \\
\hline Nuclear submarines & $\begin{array}{l}\text { Liquid and solid waste storage facilities; liquid waste } \\
\text { discharged to sea. Total activity is } 36 \mathrm{TBq} \text {. }\end{array}$ \\
\hline $\begin{array}{l}\text { Nuclear icebreakers and } \\
\text { container ships }\end{array}$ & $\begin{array}{l}\text { Liquid and solid waste storage facilities; liquid waste } \\
\text { discharged to sea. Total activity } 2.0 \times 10^{4} \mathrm{TBq} \text {. }\end{array}$ \\
\hline $\begin{array}{l}\text { Medical, research, and } \\
\text { industrial sources }\end{array}$ & $\begin{array}{l}\text { Stored at generation sites then shipped to treatment, } \\
\text { solidification, or disposal facilities near major cities. } \\
\text { Total activity is } 7.4 \times 10^{4} \mathrm{TBq} \text {. }\end{array}$ \\
\hline
\end{tabular}

Problems associated with the residual contamination are many and have been exacerbated by the economic and political collapse of the Soviet Union ${ }^{2}$. These include:

- The majority of existing and newly generated radioactive waste is not being treated or stabilized.

- Engineered storage facilities are no longer considered safe.

- Inadequate storage capacity for wastes from nuclear power plants, nuclear icebreakers, and submarines.

- Lack of remedial solutions for liquid radioactive wastes, slurry storage, and liquid tank wastes.

- The absence of an automated system for accounting and control of radioactive wastes and stored materials.

- The lack of systematic and standardized procedures for radioactive waste management. 
- The lack of regional repositories for radioactive wastes produced by the nuclear fuel cycle and nuclear power generation; existing repositories are aging or are at or near capacity.

- The significant quantity of accumulated wastes and the inadequacy of treatment or storage options for these contaminants increase the risk of accidents and human exposures.

In order to illustrate the complexity of these outstanding problems and the role of international approaches to their solution, three case studies involving remedial activities at different stages of the nuclear fuel cycle are described. Each of these studies represents different post-Soviet waste source terms and unique stages of the nuclear fuel cycle. In addition each relies upon multi-lateral international cooperation to effect a long-term solution. This paper extends the approach described by Tompson et al. ${ }^{1}$ by equipping emerging post-Soviet republics - stressed by Cold War environmental degradation - with tools to promote regional stability as well as improve economic conditions, educational opportunities, and public health.

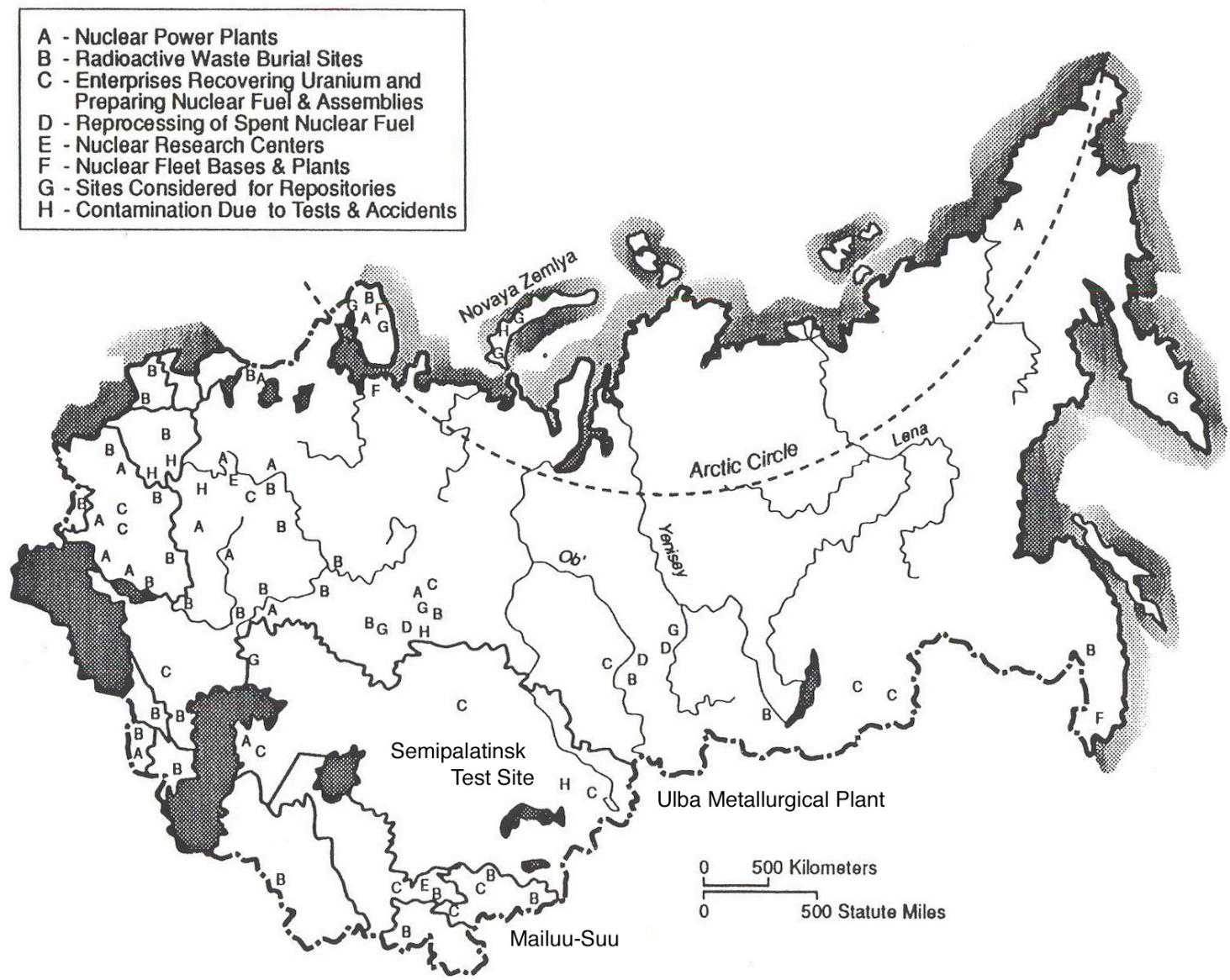

Figure 1. Nuclear waste and contamination sites in the former Soviet Union including the Semipalatinsk Test Site, Kazakhstan, the Ulba Metallurgical Plant, Kazakhstan, and Mailuu-Suu, Kyrgyzstan ${ }^{4}$. 


\section{Mailuu-Suu, Krygyzstan}

Kyrgyzstan was an important source of uranium to the former Soviet Union since the mid-1940's. Currently there are no active uranium mines. However, 23 tailing deposits and 13 waste rock dumps from Soviet uranium mining operations are located within the town of Mailuu-Suu in Kyrgyzstan ${ }^{5,6}$. Nearly $2 \times 10^{6} \mathrm{~m}^{3}$ of radioactive waste, equal to the quantity of processed ore, is prone to release through landslides to tributaries of SyrDarya River which is a main source of irrigation water for much of Central Asia. The effect of this debris on the health neighboring populations is yet completely understood.

Mailuu-Suu with a population of 26,000 people is situated in a narrow valley, prone to landslides, that drains the Mailuu-Suu River. More than 200 landslides have occurred at Mailuu-Suu over the past 30 years. The Mailuu-Suu River is a tributary of the Syr-Daria River which is primary source of irrigation to the densely populated Fergana Valley and its agricultural lands which provide crops for neighboring parts of Kyrgyzstan, Tajikistan, and Uzbekistan. The large-scale release of radioactive tailings from landslides could severely contaminate the river and downstream areas. Naturally occurring radionuclides include ${ }^{238} \mathrm{U}$ and its daughters ${ }^{226} \mathrm{Ra},{ }^{222} \mathrm{Rn},{ }^{230} \mathrm{Th}$ as well as ${ }^{210} \mathrm{~Pb}$ its daughter ${ }^{210} \mathrm{Po}^{7}$.

${ }^{222} \mathrm{Rn}$ is also released as a gas from subaerial tailings piles.

In 2002 a tailings landslide $1.2 \mathrm{~km}$ upgradient of the town dammed the Mailuu-Suu River; flooding was avoided when the river incised and breached its blockage. While the Mailuu-Suu tailings piles are entirely within Kyrgyzstan, the environmental consequences from these spoils potentially affect neighboring countries. Ethnic tensions in the Fergana Valley are likely amplified by the compromise of the main source of surface water to the region.

The government of Kyrgyzstan has acknowledged the regional environmental threats at Mailuu-Suu. Similar practices were used to mine uranium - and dispose of wastes throughout the Soviet Union and the United States during the height of the Cold War. Tailings were typically accumulated on the banks of majors rivers where they were prone to episodic flooding ${ }^{5}$. In the late 1970's the U.S. Department of Energy established the Uranium Mill Tailings Remedial Action (UMTRA) program with responsibility for reducing levels of contamination in surface waters and groundwater at sites of uranium mining and milling in the United States. Tailings were either stabilized in place or excavated and relocated to remote disposal sites. The management experience and technical information gained from clean-up at the UMTRA sites in the United States will be invaluable in planning a remedial program in Mailuu-Suu.

\section{Ulba Metallurgical Plant, Kazakhstan}

The Ulba Metallurgical Plant (UMP) is situated in Ust-Kamenogorsk, in eastern Kazakhstan. In its 50-year history of continual operation, the facility has dominated the industrial base of the city through the production of processed uranium and specialty metals such as beryllium, tantalum, and niobium. The Ulba Plant was founded in 1949 to process zinc bearing monazite ores and produce thorium oxalate. The production of 
thorium was soon discontinued and, in January 1951, the facility started to produce hydrofluoric acid and beryllium. By 1956, commercial processing of beryl ores allowed the large-scale production of high-purity beryllium oxide. Since this time, tantalum and niobium have also been refined from local ores and regularly produced as metal powders and ceramics, along with the beryllium products.

Uranium production at Ulba started in 1953 when the facility began to process uranium ore concentrates for the production of natural $\mathrm{U}_{3} \mathrm{O}_{8}$ and $\mathrm{UF}_{4}$. These processes evolved to emphasize the production of low-enriched uranium during a period when large-scale applications of nuclear power were being developed by the former Soviet Union. Ulba produced significant quantities of propulsion fuel for the nuclear navy fleet of the Soviet Union and, subsequently, Russia. In 1976 the plant started to produce fuel pellets for nuclear power plants on a commercial scale. The Ulba Metallurgical Plant produced most of the fuel for nuclear reactors constructed in the USSR between 1976 and 1990.

Accompanying the production of these metals is a significant amount of liquid waste residues, which have been, and continue to be generated and disposed of in several retention basins adjoining the facility. The discharge basins are located 3.2 kilometers from the Ulba River and 5.4 kilometers from the Irtysh River. The engineered containment barrier underlying one of the basins has failed and allowed accumulated liquid wastes in the basin to percolate into groundwater and pose a significant threat to nearby potable groundwater supplies in Ust-Kamenogorsk. Although this basin is no longer used, precipitated and other solid forms of the wastes remain in the basin, are entrained in accumulated rainfall and snowmelt, and continue to be discharged into the local groundwater as a persistent and lasting source of contamination.

The three main water supply wells for the city of Ust-Kamenogorst are situated between 3.7 and 8.2 kilometers from the basins. The water table is between 3 and 9 meters below the bottom of the disposal basins. Contaminants suspected to have originated from the Ulba Metallurgical Plant have already been detected in nearby monitoring wells and private water supply wells near the city, and the potential for contamination of public water supplies and the Irtysh and Ulba Rivers is serious.

Because they were known to be hazardous to human health and the environment, the large volumes of liquid wastes were neutralized to $\mathrm{pH} 8$ and disposed as liquid slurries into a specially designed disposal-basin facility located approximately 3 kilometers north of main production yard. The uranium concentrations in the effluent do not exceed 15 milligrams/liter. The long-term efficacy of the disposal facility relies on the delicate balance between a continuous input of the slurry-based wastes from the plant and a continuous volume reduction due to the evaporation of water from the lined and impermeable storage basins on the other. In this way, solid phase wastes that settle out in the basin or accumulate as precipitates and their corresponding dissolved waste forms remain contained in the disposal facility for long periods of time, unable to percolate into groundwater, and unable to be entrained as particulates into the atmosphere. Egorov et al. ${ }^{4}$ estimate the Ulba solid waste residuals at $1,135,000$ tons with an activity of $38 \mathrm{TBq}$ and liquid residues at $939,000 \mathrm{~m}^{3}$ with an activity of $2.3 \times 10^{-1} \mathrm{TBq}$. 
A significant portion of the effluent is insoluble and precipitates stratigraphically in the basin along the bottom and adjacent to discharge points as exposed particulate "beaches" (Figure 2). Several years ago, the delicate balance between input and evaporation rates was interrupted in the case of basin " $1-3$ " due to a significant decrease in plant production. As a result, water levels declined to the point where some of the contaminated sediments, particularly along the edge of the basin, were exposed to the atmosphere, leaving uncovered toxic "beaches" vulnerable to wind erosion and dust resuspension. More significantly, the reduced water levels led to the desiccation and partial failure (via cracking) of the clay barrier materials, which was further exacerbated by freezing conditions over one winter. The failed barrier promoted the loss of waste fluids from the basin, allowing contaminants to percolate into the local water supply aquifer and move toward nearby municipal and private water wells. Although this situation was monitored and waste streams were quickly diverted into another viable basin, rain and snowmelt have continued to accumulate in the basin and percolate downwards, entraining contaminants from the sediment "beach" materials and facilitating a steady and long term source of groundwater contamination.

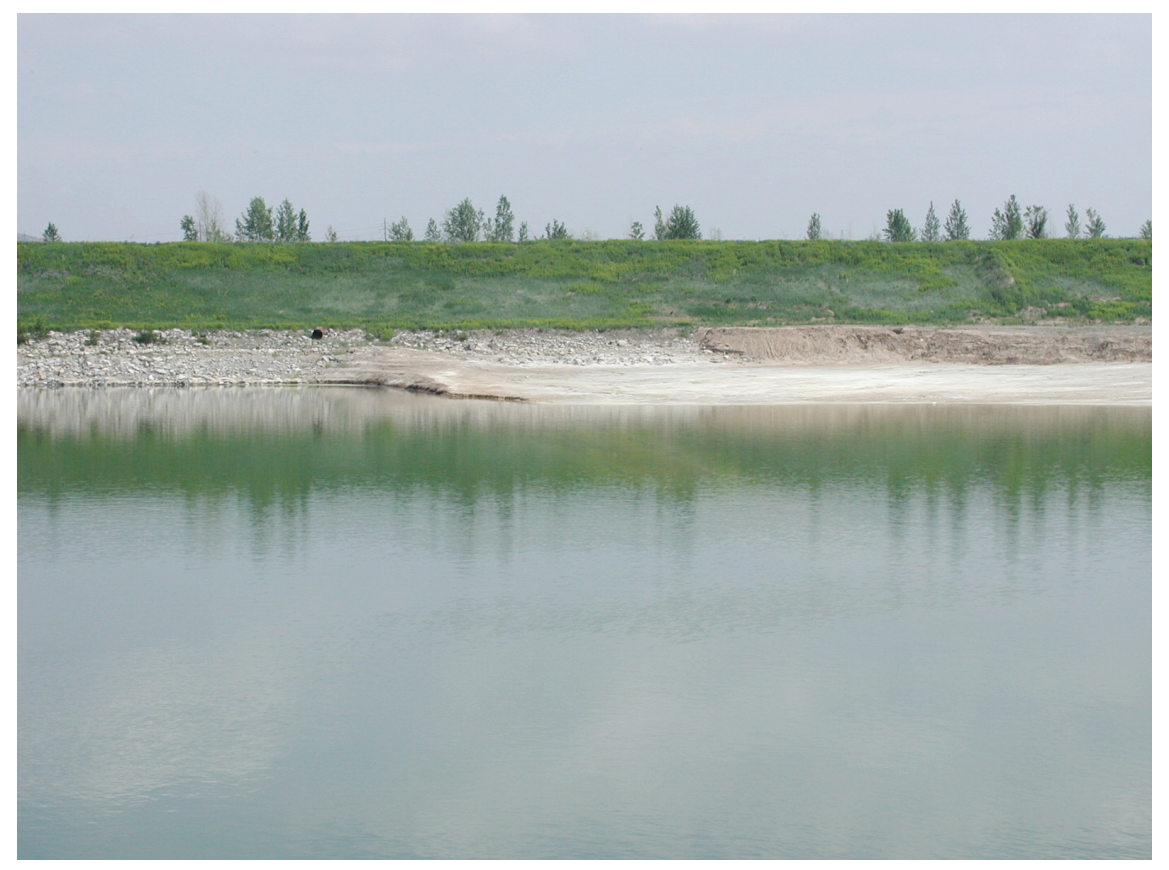

Figure 2. Particulate "beaches" adjoining retention ponds formed from the precipitation of liquid effluent accompanying uranium and beryllium production at the Ulba Metallurgical Plant.

Remedial efforts call for the development of a conceptual and numerical model of groundwater flow and chemical transport that can be used to analyze the migration of contamination in the water supply aquifers underlying the Ulba disposal basins. The model will be used ultimately as a means to protect local groundwater quality by facilitating the design of an intervention program as well as the stabilization and control of contaminant discharges from liquid waste ponds at the plant. In addition, the model 
will also be used, in its initial stages of development, to determine the need for, and guide the acquisition of additional characterization and model calibration data, and later in the design of groundwater monitoring strategies.

\section{Semipalatinsk Test Site, Kazakhstan}

The former Soviet Union conducted atmospheric and underground nuclear weapons tests at the Novaya Zemlya islands in the Russian Arctic, at the Semipalantinsk Test Site in eastern Kazakhstan, as well as peaceful nuclear explosions (PNEs) throughout its territory. The weapons program supported a Cold War program of nuclear weapons development and testing as well as, in the case of PNEs, scientific studies that included seismic research, creation of underground storage cavities, and the enhanced recovery of mineral resources. The Soviet Union conducted 715 nuclear explosions from 1949 to 1990. This includes 130 explosions at Novaya Zemlya, 456 at Semipalatinsk, and 129 conducted elsewhere (primarily PNEs) ${ }^{2,4}$. The total explosive yield of all detonations conducted at Novaya Zemlya and Semipalatinsk is $\sim 265$ megatons and $\sim 17.4$ megatons, respectively. PNEs have a total yield of $\sim 1.6$ megatons. These compare to the $\sim 200$ megaton total yield from atmospheric and underground tests conducted by the United States ${ }^{8}$.

While more information has been recently published on the nuclear testing program of the former Soviet Union ${ }^{9,10,11,12}$, little data exists on the absolute amount of radioactivity affecting surface waters or groundwaters adjacent to these nuclear test sites.

The first and the majority $(\sim 65 \%)$ of nuclear tests conducted by the former Soviet Union were conducted at the Semipalatinsk Test Site (STS). STS was selected as the location of the first Soviet nuclear test (a plutonium device code-named RDS-1 with a 22 kiloton total nuclear yield) in August, 1949. The test site was selected in 1948 due to it desertlike setting, a large remote expanse more than 200 kilometers in diameter, and proximity to an airfield and railhead; the site is $160 \mathrm{~km}$ west of the town of Semipalatinsk on tributaries of the Irtysh River. From 1949 until 1962 atmospheric tests were conducted; from 1962 to 1989 STS hosted underground tests. In total, 456 atmospheric and underground nuclear tests were detonated there; of these $70 \%$ were underground tests.

Testing was confined to distinct and spatially separated experimental areas. The northern "Test Field" was used for atmospheric and ground testing of nuclear weapons. Proof-ofprincipal experiments were conducted there as were nuclear weapons effects studies on simulated civilian and military targets. Surface explosions conducted in 1949, 1951 and 1953 released some $8.33 \times 10^{2} \mathrm{TBq}$ of ${ }^{90} \mathrm{Sr}, 1.2 \times 10^{3} \mathrm{TBq}$ of ${ }^{137} \mathrm{Cs}$ and $34.8 \mathrm{TBq}$ of $\mathrm{Pu}$ of radioactivity (decay corrected to 1994) to the environment ${ }^{4}$. Neighboring cities, including Dolon to the northeast of the test site, were exposed to large doses of radioactivity; nearly 10,000 people of a total population of 70,000 received radiation during the atmospheric testing periods from 1949 to $1963^{2}$. Subsequent international radiological monitoring by the International Atomic Energy Agency in 1993 and 1994 determined that radioactivity from these atmospheric tests is currently confined to areas 
immediately surrounding ground zeros and no longer poses a health risk to nearby populations ${ }^{13}$.

Underground nuclear testing was conducted in tunnels and adits $200 \mathrm{~m}$ to $2 \mathrm{~km}$ long cut in the Degelen Mountain massif, at the bottom of $200 \mathrm{~m}$ to $2 \mathrm{~km}$ deep vertical shafts, 1 meter in diameter, drilled in the Lake Balapan test area, and within auxillary vertical shafts in the Murzhik Site. 209 tests were conducted at Degelen Mountain, 105 tests were conducted at Lake Balapan, and 26 underground tests were conducted at Murzhik. Degelen is a granite rock intrusion that is characterized by geologic faults and extensive fracturing; surface water actively recharges this area and results in perched groundwater with flow rates in excess of $3000 \mathrm{~L} /$ minute in some areas ${ }^{11}$. The geologic setting of the Balapan area is equally complex with steeply dipping and faulted sediments and metasediments. Groundwater is located in areas of tectonic faulting; the depth to groundwater is between 5 to $15 \mathrm{~m}$ below the ground surface.

Containment of underground nuclear tests at the STS was inadequate. After the signing of the Limited Test Ban Treaty in 1963, standard practice called for all underground nuclear tests to incorporate measures to prevent the release of radionuclides to the atmosphere. Containment required the nuclear explosion to be conducted in rock with sufficient strength and spacing between tests that it would not mechanically fail due to the force of the detonation. In addition, the tunnels or boreholes were further sealed with backfill and grouting materials ${ }^{10}$. However, only $50 \%$ of Soviet underground tests qualified as 'full camouflet explosions' where radioactivity was fully contained underground. $45 \%$ of the explosions were 'partial camouflet explosions' where there was some leakage of radioactive noble gases (e.g., ${ }^{131 \mathrm{~m}} \mathrm{Xe} \mathrm{t}_{1 / 2}=11.9$ days; ${ }^{133 \mathrm{~m}} \mathrm{Xe} \mathrm{t}_{1 / 2}=2.2$ days; ${ }^{133 \mathrm{~g}} \mathrm{Xe} \mathrm{t}_{1 / 2}=5.2$ days; ${ }^{135 \mathrm{~g}} \mathrm{Xe} \mathrm{t}_{1 / 2}=9.1$ hours; ${ }^{37} \mathrm{Ar} \mathrm{t}_{1 / 2}=35.0$ days) from ground zero to the atmosphere (Figure 3). Thirteen tests at STS were 'partial camouflet explosions' with non standard radiation releases to the environment. These containment accidents deviated substantially from standard testing practice and resulted in radiological exposures to neighboring human populations in excess of maximum permissible concentrations. 


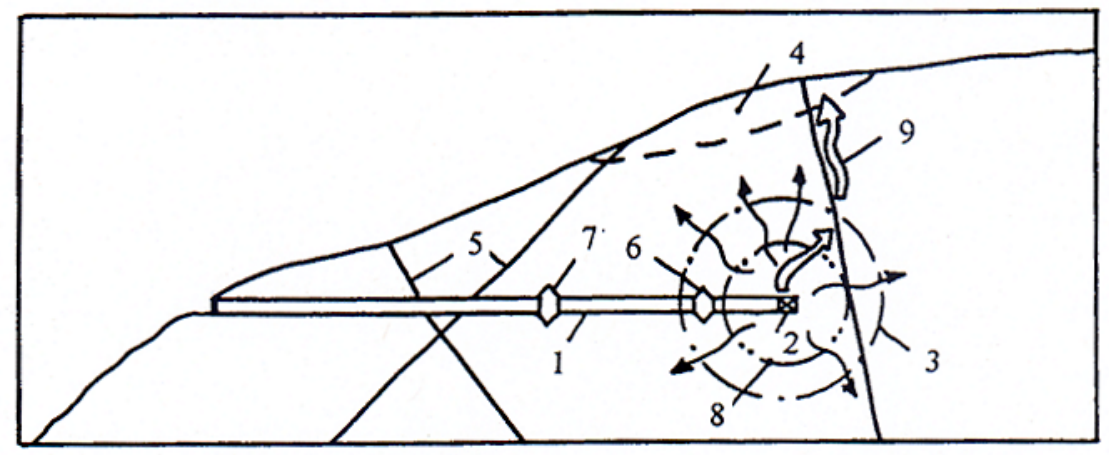

Figure 3. Schematic of gas release and venting through a geologic fault from a nuclear test conducted in a tunnel at Degelen Mountain. $1=$ tunnel; $2=$ zero room; $3=$ damaged rock radius; $4=$ surface spall zone; 5 geologic faults; 6 and 7 containment stemming; $8=$ radius of gas transport; $9=$ gas flow through tectonic fault ${ }^{10}$.

The International Atomic Energy Agency has determined that surface contamination from atmospheric nuclear test contamination $\left(\sim 185 \mathrm{GBq} / \mathrm{km}^{2}\right)$ quickly falls to background in a radial direction away from the center of these explosions ${ }^{13}$. However, the radiological effects of nuclear testing are yet to be fully understood. Recent reports indicate the presence of large quantities of unsecured plutonium metal available on the surface of parts of the test site ${ }^{12}$. The health and proliferation threat is only compounded as the local nomadic population of eastern Kazakhstan repopulates the lands of the Semipalatinsk Test Sites and reverts to traditional livelihoods of grazing and agriculture. In addition proven mineral reserves of $\mathrm{Cr}, \mathrm{Cu}, \mathrm{Pb}, \mathrm{W}, \mathrm{Mo}, \mathrm{Au}$ exist in more than 30 mapped ore deposits. Coal mines within the borders of the STS are also actively being mined.

Due to the poor record of containment the potential for contamination of groundwater and ensuing risk to down-gradient receptors remains high. At Degelen Mountain, nuclear testing resulted in severe structural damage to the rock itself. Twenty seven tunnels are discharging water and 24 tunnel entrances (out of 127 adits) are contaminated by measurable levels of ${ }^{90} \mathrm{Sr},{ }^{137} \mathrm{Cs}$ and ${ }^{239} \mathrm{Pu}$. Deterioration of the aging tunnel workings only has hastened the migration of radionuclides. At the Balapan test area, the release of gaseous radionuclides due to venting was widespread; like Degelen, the force of the explosion has weakened the structural integrity of the rock surrounding the explosions and has increased the likelihood of radionuclide migration in groundwater. Methane present in some boreholes due to the breakdown of organic-rich shales and coals has also resulted in spontaneous combustion and burning of some shafts ${ }^{11}$. The maximum extent of groundwater contamination requires further study; however, ambient groundwater velocities are enhanced by the permeability afforded both by tectonic and test-induced fracturing. Concentrations of tritium, ${ }^{90} \mathrm{Sr}$, and ${ }^{137} \mathrm{Cs}$ have been measured in groundwaters of the Degelen and Balapan testing areas. At the Balapan test area groundwaters produced from an unused borehole (no. 1419) have a tritium concentration of $1.4 \times 10^{6} \mathrm{~Bq} / \mathrm{L}$ and a ${ }^{90} \mathrm{Sr}$ concentration of $2.0 \times 10^{3} \mathrm{~Bq} / \mathrm{L}$; the nearest nuclear test was 1 kilometer distant. Clearly, groundwater is currently mobilizing radionuclides, but the 
nature, extent, and velocity of the transport is unknown and requires comprehensive investigation.

For these reasons, scientists from the National Nuclear Center of Kazakhstan, the Russian Academy of Sciences and the U.S. defense programs national laboratories (with support from U.S. Government) have initiated a collaboration to address the problem of the extent of groundwater contamination from the underground nuclear tests conducted at the STS. These efforts incorporate a combined approach that relies on field and laboratory investigations to return data on the extent of radiochemical contamination of groundwater. In turn this data will be used to construct hydrologic flow and coupled contaminant transport models that can be used to assess and manage the present and future spread of contamination as well as effective plan for long-term radiological monitoring to best protect the human health and the environment. These methods have proven successful to address the migration of radionuclides in groundwater, and dose to potential downgradient receptors, at sites of underground nuclear tests conducted by the United States ${ }^{14}$.

\section{CONCLUSIONS}

In describing several case studies of radioactive contamination in states of the former Soviet Union, the role of the international community to address these problems cannot be underestimated. The residual contamination described here is daunting, affects large numbers of people, crosses political borders, is hydrochemically complex, as well as requires critical strategies (and technologies) for effective long-term solutions. For these reasons, cooperative approaches using science and technology provide common tools that combine the capabilities of military, academic, ministerial, private organization, and other partners ${ }^{1}$. The long-term viability of emerging post-Soviet governments hinges on their ability to effective solve legacy environmental problems and best protect their citizens by promoting responsible environmental and economic practices. As such, this is also very much a national security issue. Due to the new access afforded to the territories of the former Soviet Union by the end of the Cold War, as well as organizations and funding to promote international partnerships, the many threats from radionuclide contamination within the former Soviet Union can now be fully evaluated and potentially mitigated.

\section{ACKNOWLEDGEMENTS}

This work was performed under the auspices of the U.S. Department of Energy by the University of California, Lawrence Livermore National Laboratory under Contract No. W-7405-Eng-48. 


\section{REFERENCES}

1. Tompson, A.F.B., Richardson, J.H., Ragaini, R.C., Knapp, R.B., Rosenberg, N.D., Smith, D.K., and Ball, D.Y., 2002, Science and technology to advance regional security in the Middle East and Central Asia, Lawrence Livermore National Laboratory, UCRL-JC-150576, 17p.

2. Bradley, D.J., 1997, Behind the nuclear curtain: radioactive waste management in the former Soviet Union, (D.R. Payson, ed.), Battelle Press, 716p.

3. Bradley, D.J., Frank, C.W., Mikerin, Y, 1996, Nuclear contamination from weapons complexes in the former Soviet Union and the United States, Physics Today, v. 49 , p. 40-45.

4. Egorov, N.N., Novikov, V.M., Parker, F.L., Popov, V.K. (eds.), 2000, The radiation legacy of the Soviet nuclear complex, London: Earthscan Publications Ltd., 236p.

5. Buckley, P.B., Ranville, J., Honeyman, B.D., Smith, D.K., Rosenberg, N. and Knapp, R.B., 2003, Progress toward remediation of uranium tailings in Mailuu-Suu, Kyrgyzstan. In Proceedings of Tailings and Mine Waste '03, Vail, Colorado, 1215 October, 2003. Rotterdam: Balkema.

6. Knapp, R.B., Richardson, J.H., Rosenberg, N., Smith, D.K., Tompson, A.F.B., Saranogoev, A., Duisebayev, B., Janecky, D., 2002, Radioactive tailings issues in Kyrgyzstan and Kazakhstan. In Proceedings of Tailings and Mine Waste '02, Fort Collins, Colorado, 27-30 January, 2002. Rotterdam: Balkema.

7. U.S. Army Center for Health Promotion and Preventive Medicine (USACHPPM), 1999, radiological sources of potential exposure and/or contamination, TG-238, 285 p.

8. United Nations Scientific Committee on the Effects of Atomic Radiation (UNSCEAR), 1998, Exposures from man-made source of radiation, 47th Session of UNSCEAR, 130p.

9. Tsaturov, Y.S., Matushchenko, A.M., Dubasov, Y., Krasilov, G.A., Logachev, B.A., Maltsev, A.L., Safronov, V.G., Filippovski, V.I., Smagulov, S.G., 1998, Semipalatinsk and northern test sites in the USSR: integrated program of radiation and ecological studies on environmental consequences of nuclear tests, in Atmospheric Nuclear Tests: Environmental and Human Consequences, (C.S. Shapiro, ed.) Springer-Verlag, p. 199-218.

10. Adushkin, V.V. and Leith, W., 2001, The containment of Soviet underground nuclear explosions, U.S. Geological Survey, Open File Report 01-312, 52p. 
11. Shkolnik, V.S. (ed.), 2002, The Semipalatinsk Test Site: creation, operation, and conversion, Sandia National Laboratories, SAND 2002-3612P, 396p.

12. Stone, R., 2003, Plutonium fields forever, Science, v. 300, p. 1220-1224.

13. International Atomic Energy Agency (IAEA), 1998, Radiological conditions at the Semipalatinsk Test Site, Kazakhstan: preliminary assessment and recommendations for further study, International Atomic Energy Agency STI/PUB/1063, 43p.

14. Tompson, A.F.B., Bruton, C.J., Pawloski, G.A. (eds.), 1999, Evaluation of the hydrologic source term from underground nuclear tests in Frenchman Flat at the Nevada Test Site: the CAMBRIC test, Lawrence Livermore National Laboratory, UCRL-ID-132300, 319p. 